McDowell." She represented that she needed the money, and most of those who subscribed paid cash. She must have received over fifty orders here, and several hundred each in Detroit and Cleveland, nearly all paying cash. We can not get any clue to her location nor can we get the books. The publisher says that the edition is exhausted and not paid for and of course will print no more.

Considering the possible magnitude of the swindle, I write to ascertain how to check it. If you desire it, can get the statements of those who paid in this city.

Yours truly,

Thomas Hebrard,

Secretary, Ohio State Medical Society.

Objects to the Term "Jackass."

Detroit, Mrcir., Oct. 25, 1893.

To the Editor:-The scientific language used in the argument by Dr. Solomon Solis-Cohen against Dr. John B. Roberts and his article, "The Similarity between Physicians and Homeopaths," is worthy of remark. His article is illiberal, un-American, and based upon an unscientific principle of thought. A principle of science that has been accepted by all civilization is true; but a principle of science which has not reached its perfection and its acceptance by the whole civilized world is not true, as yet. The paper, as a whole, was more suitable for a political gathering than a scientific society. No matter what ideas a man may have, he is never to be compared to a mule or a jackass. It is ungentlemanly to speak thus of a class of excellent men who are entitled to the respect of those who can not agree with them. Louis Edelman, M.D.

\section{Proposed Change of Name.}

Chattaxooga, Texn., Oct. 24, 1893.

To the Editor:-Apropos of your editorial, "Try a New Name," I would state that the Tri-State Medical Society of Alabama, Georgia and Tennessee will at its next meeting vote on a proposition to change the name to the Southeastern Medical Society. The next meeting will be held in Atlanta on the second Tuesday in October, 1894. Fraternaliy,

Frank Trester Smith, Sec'y.

\section{MISCELLANY.}

Pittston, Pa. New Hospital.-A fine Cottage Hospital 88 x 44 feet, was opened October 24, at Pittston, Pa.

The College of Physicians and Surgeons of Richmond, Va., have purchased the Richmond City Hospital for $\$ 18,489.39$.

Lowell, Mass., Hospital:-A nine thousand dollar addition is to be built to the Lowell, Mass., Hospital.

Robbed a Hospital.-A patient at the Louisville City Hospital, robbed the hospital October 19, of all the surgical instruments he could conveniently carry away. The thief was caught and most of the instruments recovered.

Rich Legacies for Hospitals.-The New York Hospital and the Presbyterian Hospital are among the residuary legatees of an estate, the proceeds of which, it is estimated, will yield $\$ 200,000$ to each of these charities

Reichenau Consumptive Hospital.-Baron Nathaniel Rothschild's plan of presenting the consumptives of Vienna with a castle at Reichenau has aroused great opposition in that neighborhood, which is a delightful summer resort. The landlords and others fear that the presence of so many sick people will drive away the guests who come there for pleasure. But the chief objection comes from the Emperor's brother, the Archduke Charles Louis, who quarrelled with the Baron some time ago because he declined to sell the eastle to the Duke. When the money prince found that the Duke had set his heart on getting possession of the castle he straightway decided to convert it into a hospital.
New Hospital at Rhinelander, Wis.-The Sisters of Charity at Rhinelander, Wis., are to have a new hospital building. that will cost $\$ 20,000$.

A Dispensary Burned.-The dispensary of the New York Presbyterian Hospital was destroyed by fire October 21.

Change of Address.-Dr. Bayard Holmes to 104 East Fortieth Street, Chicago.

Want a Bacteriologist.-The Board of Health of Syracuse, $N$. Y., have asked the city council for the appointment of a bacteriologist to verify diagnoses of diphtheria.

Private Fire-Service in a Hospital.-A destructive hospital fire was probably prevented by a private apparatus, at the New York Presbyterian Dispensary. The conflagration was. started early on a Sunday morning,in an underground apartment where turpentine and other combustibles were stored. The private fire apparatus was put in operation in a few minutes. The city fire engines came soon afterwards and with several streams of water pouring into the blazing storeroom, all danger from a spread of the flames was overpast in less than twenty minutes. The total loss on drugs. and furniture in dispensary and drug room is estimated at $\$ 3,000$. With a less degree of preparation, and a few minutes longer delay in handling the fire, the loss might readily have been quadrupled. A good private fire service in hospitals or asylums is a "modern improvement" that can not be overlooked or slighted.

Ohio Railway Surgeons.-At the meeting of the Ohio Railway Surgeons the following officers were elected for 1894: President, W. A. Ward of Conneaut; Vice-President, B. M. Ricketts, Cincinnati; Second Vice-President, IV. S. Hay, Wellston. Chas. H. Mertz, Toledo, Secretary.

New York Quarantine Commission.-The Board of Quarantine Commissioners met in the Mayor's office October 18, and awarded to Colin McLean additional contracts for the improvement of buildings on Swinburne and Hoffman Islands, to the amount of $\$ 21,099$. It also allowed Dr. Jenkins, $\$ 9,281$ to pay bills contracted during the cholera scare of last year.

Tri-State Medical Journal.-Dr. James Moores Ball of Keokuk, Iowa, is to be the Editor-in-chief of a new medical journal, to be called the Tri-State Medical Journal. The initial number will appear December 1, and reappear each month thereafter.

The Medical Mirror and the Congress.-The St Louis Medical Mirror devotes the entire October number to the proceedings of the Pan-American Medical Congress. Among its other features of interest is a stenographic report of the speeches at the editors' banquet.

A Group of Connecticut Triplets.-A thirteen-year-old matron of Roxbury, has given birth to triplets-one boy and two girls-weighing in all twenty-three pounds. The age of the father is sixteen years. The mother is robust and developed beyond the average of girls of her age. She is the danghter of a farmer and her husband is a farm-hand.

A Venerable Pioneer Physician.-Dr. Frederick Andros, of Mitchell, S. D., claims to be the first authorized practitioner of medicine not only in Dubuque, Iowa, but also in the immense region west of the Mississippi River to the Pacific north of the Missouri River. He is a native of Massachusetts and now nearly 91 years of age.

Sick Men as Bank Assets.-The Metropolitan National Bank of Kansas City, recently sued Mr. Frank E. Tyler of that eity and attached his property. It seems that he was President of the Church Charity Association which established All Saints Hospital and had advanced that institution some $\$ 14,707.73$, which on demand of the bank, the hospital was unable to pay. The bank therefore has come 